\title{
Designation of the senior types of Paraproba pendula Van Duzee, 1914, and a key to the North American species of Paraproba (Hemiptera:Miridae) ${ }^{1}$
}

\author{
J. Maldonado Capriles"., \\ ABSTRACT \\ The senior types of Paraproba pendula are assigned. The species is \\ redescribed and a key is given to the North American species of this genus.

\section{INTHODUCTION}

E. P. Van Duzee described Paraproba pendula without assigning senior types. I herein select these types after studying the series of specimens which Van Duzee used for the description of the species. Below I redescribe the species using the colors mentioned by Van Duzee", illustrate the male genitalia, and give a key to the North American species in the genus. It is interesting to note that all the North American species are known only from California.

The types are deposited in the collection of the Museum of the California Academy of Science at San Francisco, Golden Gate Park. Measurements are given in $\mathrm{mm}$.

\section{DESCRIPTIONS}

\section{Paraproba pendula Van Duzee, 1914}

Paraproba pendula Van Duzee, 1914. Trans. S. Diego Soc. Nat. Hist. 2:25. California, U. S. A.

Male-Overall coloration yellowish white and with mostly black pronotum, head, and antennae (Plate I, fig. 6). Head black, the base behind the eyes ochraceous; gula fuscous. Antenna black, the base of segment I pale. Pronotum: calli blackish, ochraceous before and after calli extending to disk. Mesoscutum with middle third black, on either side orangeyellow. Scutellum black. Hemelytra whitish subhyaline, more or less

${ }^{1}$ Manuscript submitted to Editorial Board December 1, 1980.

"Department of Anatomy, Ponce School of Medicine, Ponce, P. R.; and Department of Plant Protection, College of Agricultural Sciences, University of Puerto Rico, Mayagüez, P. R.

"The author is indebted to P. J. Amaud from the Museum of the California Academy of Science, at San Francisco, Golden Gate Park, California, U. S. A. for the Loan of specimens.

"Van Duzee, E. P., A preliminary list of the Hemiptera of San Diego County, California, Trans. S. Diego Soc. Nat. Hist. 2 (1): 1-57, 1914. 
SENIOR TYPES OF P PENDULA AND kEY TO PARAPROBA SPP. 283

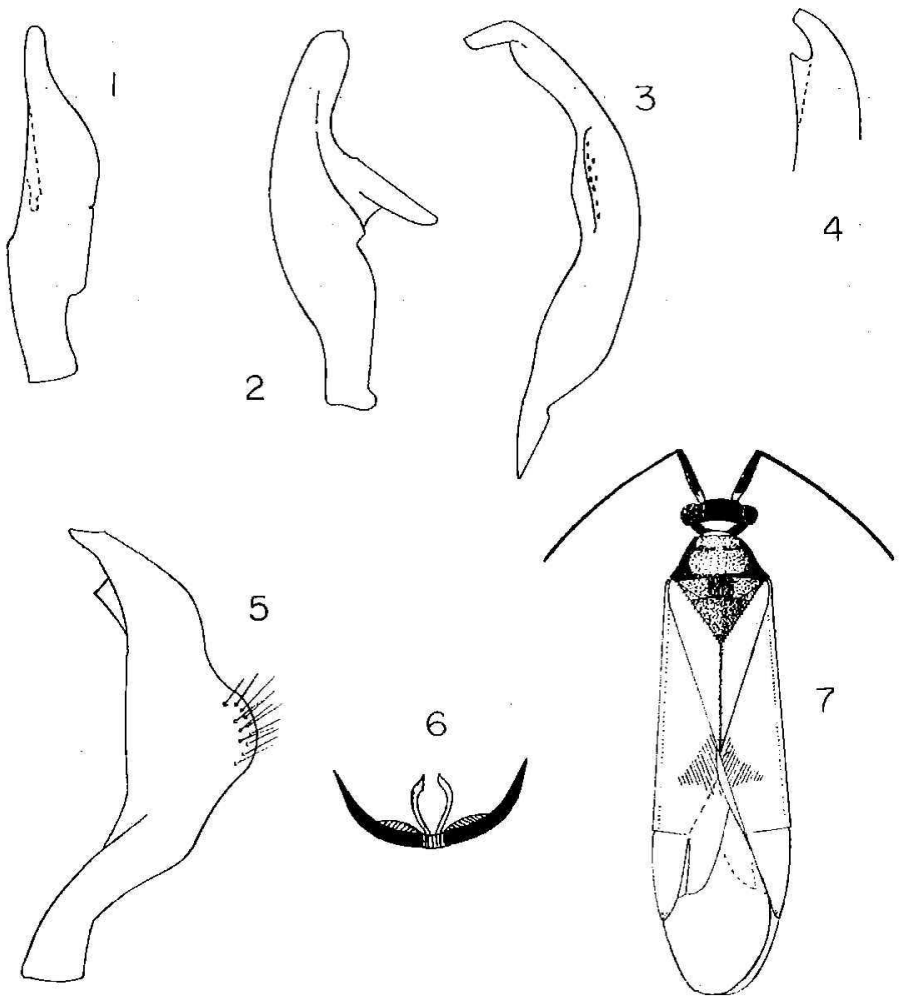

Plate I.-Paraproba pendula Van Duzee. 1. Right clasper, lateral. 2. Kight clasper, dorsal. 3. Left clasper, lateral external. 4. Apex of left clasper, ventroapical. 5. Left clesper, dorsal. 6. Claws. 7. Habitus.

tinged with bluish green; narrow scutelar and commissural margins of clavus, blackish, this line connecting with grayish transverse (Van Duzee describes this as oval) spot on the inner angle of the corium. Membrane hyaline, iridescent, with a discal very faint smokey cloud, the nervures brownish. Beneath with pale beak and what is left of the legs, mesopleura, metapleura, and genital capsule blackish, the latter with apical margin yellowish.

Head across eyes 0.6 , vertex 0.25 , length 0.3 . Antennal segments: I, 0.45 ; 
II, 1.5; III-IV missing; pilose very short, fine. Pronotum: posterior width 0.75 , length 0.34 , scutellum as long as wide, 0.4:0.4. Genital segments as in figures 1 to 5 . Length $4.2 \mathrm{~mm}$.

Female-Coloration much as in male; the ochraceous behind the calli about as long as in male; the left metafemur blackish anteriorly; the right blackish above; last abdominal segment polished blackish brown.

Head across eyes 0.55 , vertex 0.25 , length 0.25 . Antennal segments: I, 0.41 ; II, 1.1; III, 0.55; IV missing. Pronotum: posterior width 0.75 , length 0.35 , posterior margin slightly broadly concave. Mesoscutum 0.15 long; scutellum width 0.45 , length 0.35 . Length $3.5 \mathrm{~mm}$.

Lectotype--Male, Palo Alto Cal., September, J. C. Bradley collector, E. P. Van Duzee collection, a label with Van Duzee's handwriting reading "PARATYPE pendula." California Academy of Science Number 2079. Allolectotype, female, Leona Heights, Alameda County, Cal., August, J. C. Bradley, labeled "PARATYPE pendula" in Van Duzee's handwriting, Number 2080. PARALECTOTYPES: 4 females, Leona Heights, Alameda County, J. C. Bradley collector, a label as in the lectotype, two on the same pin, the third in another pin together with a specimen without abdomen. A fifth paralectotype is labeled Leona Hgts,, Oakland, Cal., August, J. C. Bradley, and a label as the lectotype.

\section{DISCUSSION}

As pointed out by Van Duzee pendula looks much like a Dicyphus. Van Duzee could not see the arolia, and thus cautiously wrote "Paraproba differs from Dicyphus chiefly in the form of the pronotum and may have to be merged with it after a more careful study". I can see the arolia in the specimens from Leona Heights as well as in those from San Diego (fig. 6). The more extensive whitish on the disk of the pronotum, the lack of black in the middle third of the mesoscutum, and the slightly shriveled condition of the specimens from San Diego make me think that they are teneral. They may be a different species, but unfortunately there is no male in the series. In one of these specimens the beak slightly surpasses the posterior coxae. Thus, even though the specimens from San Diego have the general appearance of a Dicyphus, a genus in the Phylinae because it lacks arolia, they belong in the Orthotylinae because they have typical convergent arolia. The head of all the specimens is oval and with medium sized eyes instead of the slightly elongate head with small eyes at about midlength of Dicyphus. On the other hand, all the specimens of Paraproba from the Neotropics before me have somewhat bulging and proportionately larger eyes. The right clasper (fig. 1 and 2) is very similar to that of other species of Paraproba in my collection; the left is quite different (fig. 3 to 5). The aedeagus is 
SENIOR TYPES OF P. PENDULA AND KEY TO PARAPROBA SPP. 285

simple, long, and tapers to a fine point and the vesica is a simple covering tapering sheath.

\section{KEY TO THE NORTH AMERICAN SPECIES OF PARAPROBA}

1. Corium with large subapical spot; pronotum mostly black, with orangeyellow before and after black calli, sometimes the latter area extending well into the disk .............. Pendula Van Duzee, 1914 Corium without such spot; pale delicate species without black on pronotum . . . . . . . . . . . . . . . . . . . . . 2

2. I antennal segment black, others yellowish white; most of the vein of the large cell of the membrane and tip of cuneus blackish . . . . . . . . . . . . . . . . P. nigrinervis Van Duzee, $1917^{i}$

I antennal segment mostly yellow, others yellowish white ...... 3

3. I antennal segment yellowish, with black lateral longitudinal stripe; veins of membrane black; apex of corium without pale greenish areas $\ldots \ldots \ldots \ldots \ldots \ldots \ldots \ldots \ldots$. cincta Van Duzee, $1917^{5}$ I antennal yellowish-white, without such black line; veins of membrane light, concolorous with membrane; with inconspicuous, undefined

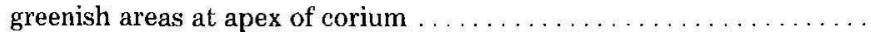

P. hamata Van Duzee, $1912^{6.7}$

\section{RESUMEN}

En el presente trabajo se señalan los lectotipos de Paraproba pendula Van Duzee 1914, ya que él no escogió los tipos. Se redescribe la especie, se confirma la posición de ésta en Orthotylinae y se presenta una clave para las cuatro especies del género en América del Norte.

"Van Duzee, E. P., Report upon a collection of Hemiptera made by Walter M. Giffard in 1916 and 1917, chiefly in California, Proc. California Acad. Sci, 7 (4): 249-319, 1917.

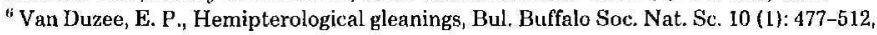
1912.

${ }^{7}$ Van Duzee, E. P., Notes on some Hemiptera taken near Lake Tahoe, California, T'ech. Bul. Univ. California Agric. Exp. Stn. 1: 229-49, 1916. 